\title{
EDITORIAL
}

\section{GOD OF SORROWS IN THE MAN OF SORROWS}

\section{Audy Santoso}

Di dalam Alkitab, salah satu gelar yang melekat pada Yesus Kristus berasal dari Yesaya 53, The man of Sorrows. Penderitaan yang dialami oleh Kristus bukan saja penderitaan fisik, melainkan juga jiwa/mentalnya. Sebagai manusia sejati, Kristus memiliki natur manusia seutuhnya termasuk aspek emosi. Ayat-ayat seperti Matius 5:4 dan Matius 26:37 menegaskan bahwa Kristus mengajarkan, bahkan mengalami emosi kedukaan yang benar dan kudus. Pada hakikatnya memiliki emosi bukanlah hal yang berdosa.

Kecurigaan umum akan emosi yang perlu dikontrol oleh rasio merupakan warisan dari pemikiran Yunani Kuno yang membagi manusia dalam 3 aspek: Rasio - Emosi - Kehendak. ${ }^{1}$ Namun pemikiran ini menyesatkan dan pernah disanggah kebenarannya oleh Blaise Pascal (1623-62), yang dalam kumpulan tulisannya Pensées menuliskan, "the heart has its reasons, which reason does not know." ${ }^{2}$ Rasio merupakan suatu proses berpikir yang terstruktur untuk mendapatkan suatu pengetahuan, namun hati mengakses pengetahuan secara langsung di dalam pertimbangannya. Rasio sering dijadikan hakim terakhir, padahal rasio sendiri memiliki 3 sifat yang menentang kemungkinan ini. Pendeta Dr. (h.c.) Stephen Tong mengidentifikasikan batasan rasio sebagai berikut, "human reason is created, limited, and polluted." Itu sebab rasio tidaklah berkedudukan lebih tinggi daripada emosi manusia. Baik rasio maupun emosi berasal dari tempat kedudukan yang sama, yaitu hati manusia. Hati manusia yang tercemar, bukan saja mencemari emosinya, namun juga rasionya.

Salah satu pemikiran Yohanes Calvin yang jarang disoroti adalah pandangan bahwa seluruh hidup Kristus adalah pelayanan salib. Di dalam

\footnotetext{
1 Bdk. pembahasan oleh Hans Boersma, Seeing God: The Beatific Vision in Christian Tradition (Grand Rapids: Eerdmans, 2018), 48-68.

2 Blaise Pascal, Pensées, trans. W. F. Trotter. (1660), 277. Diakses online pada https://ccel.org/ccel/ pascal/pensees/pensees.v.html
} 
Institutes of Christian Religion 3.8.1, Calvin mengatakan, "...the whole life of Christ was nothing but a sort of perpetual cross." Salib tidak direduksi oleh Calvin dalam peristiwa kematian dan kebangkitan Kristus saja, namun keseluruhan hidup Kristus. Maka kehidupan Kristus sepanjang hidupnya di dunia sebagai the man of sorrows dapat dikatakan sebagai pelayanan kedukaan. Pengakuan iman Nicea (325 M) menyatakan inkarnasi Kristus adalah "bagi kita dan bagi keselamatan kita." Maka emosi pergumulan dukacita Kristus pun di dunia adalah suatu salib yang berkelanjutan yang ditanggungnya "pro nobis, bagi kita". Duka Kristus bahkan masih berlanjut hingga saat ini ketika Kristus duduk di sebelah kanan Allah. Kristus menderita saat gerejaNya teraniaya; "Saulus, Saulus, mengapakah Engkau menganiaya Aku?" (Kisah Para Rasul 9:4).

Di dalam mengenal Kristus, kita mendapatkan pengenalan akan Allah yang sejati (Bdk. Yohanes 1:18, mengenal Bapa). Oleh karena itu, pengenalan kita akan Kristus sebagai the man of sorrows membawa kita mengenal bahwa Allah pun adalah God of sorrows. Hal ini tidaklah mengherankan karena kita dapat menemukan Allah yang menderita, baik di Perjanjian Lama di dalam Kitab Yehezkiel 33:11

Katakanlah kepada mereka: Demi Aku yang hidup, demikianlah firman Tuhan ALLAH, Aku tidak berkenan kepada kematian orang fasik, melainkan Aku berkenan kepada pertobatan orang fasik itu dari kelakuannya supaya ia hidup. Bertobatlah, bertobatlah dari hidupmu yang jahat itu! Mengapakah kamu akan mati, hai kaum Israel?

\section{maupun di Perjanjian Baru di dalam Roma 2:4}

Maukah engkau menganggap sepi kekayaan kemurahan-Nya, kesabaran-Nya dan kelapangan hati-Nya? Tidakkah engkau tahu, bahwa maksud kemurahan Allah ialah menuntun engkau kepada pertobatan?

Allah yang kita percaya memang Allah yang tidak berubah, di dalam diriNya. Namun di dalam berelasi dengan dengan umatNya, Tuhan pun dapat menyembunyikan wajah-Nya (Bdk. Yesaya 8:17). Sedangkan mengenai pribadi ketiga Allah Tritunggal, tulisan dari Paulus begitu jelas menyatakan kemungkinan Roh Kudus dapat didukakan. Efesus 4:30, “Janganlah kamu mendukakan Roh Kudus." Membuat seseorang menjadi marah adalah perkara yang jauh lebih mudah dibandingkan membuat seseorang berduka. Untuk berduka, diperlukan suatu relasi yang dekat, bahkan akrab yang mengakibatkan dapat terjadinya kedukaan yang dalam. Maka Allah Tritunggal yang dimana melalui pengenalan akan Kristus, kita kenal sebagai Allah yang menderita (God of sorrows). 
Pengenalan kita akan Kristus sebagai the man of sorrows, dan Allah sebagai God of sorrows memberikan penghayatan akan diri kita yang dicipta dalam rupa dan gambar Allah untuk memiliki dukacita yang benar. Kehidupan Kristus yang berinkarnasi menjadi manusia adalah pro nobis, termasuk di dalam aspek emosi dukacitanya. Maka kita perlu belajar untuk melihat yang Allah lihat, mendengar yang Allah dengar, dan mengkehendaki yang Allah kehendaki. Ini ditegaskan oleh Petrus di dalam 1 Petrus 2:19, 21,

19 Sebab adalah kasih karunia, jika seorang karena sadar akan kehendak Allah menanggung penderitaan yang tidak harus ia tanggung. ... 21 Sebab untuk itulah kamu dipanggil, karena Kristuspun telah menderita untuk kamu dan telah meninggalkan teladan bagimu, supaya kamu mengikuti jejak-Nya.

Dalam edisi kali ini, jurnal Verbum Christi menghadirkan 5 artikel pilihan yang berasal dari para penulis yang merupakan mahasiswa atau lulusan serta dosen STTRII. Adapun artikel pertama, The Concept of Imago Dei in the Thought of Gerrit Cornelis Berkouwer, merupakan karya tulis Farlen I. Tatukude, lulusan STTRII dan Billy Kristanto, dosen STTRII. Tulisan ini mengkritisi pandangan Berkouwer terhadap konsep Imago Dei sebelumnya di dalam pemahaman analogia entis (dipengaruhi filsafat Yunani kuno yang rasio sebagai yang terutama) dan analogia relationis. Tatukude dan Kristanto melihat kekuatan Berkouwer dengan mengambil pendekatan kisah sejarah keselamatan yang dalam kesimpulan definisinya mengenai manusia adalah sebagai analogia amoris. Tatukude dan Kristanto juga mengkritisi kekurangan pandangan Berkouwer, khususnya di dalam ruang publik yang harusnya mencakup orang non-kristen yang juga masih memiliki keserupaan dengan Allah.

Artikel kedua masih membahas mengenai Berkouwer mengenai kebebasan manusia yang berjudul Kontribusi Gerrit Cornelis Berkouwer Terhadap Pembahasan Kebebasan Manusia. Artikel ini ditulis oleh Verawati Halim seorang lulusan dari STTRII dan Jadi S. Lima, dosen STTRII. Halim dan Lima menyoroti pergeseran pembahasan konkret kebebasan manusia kepada kehendak bebas. Terhadap pergeseran ini Berkouwer telah bersumbangsih di dalam mengembalikan kebebasan manusia untuk kembali dipahami dari sudut pandang Alkitabiah, yaitu dalam konteks relasi manusia dengan Tuhan yang bersifat esensi dan konstitutif. Kebebasan dalam relasi inilah yang meniscayakan lepasnya pembahasan kebebasan dari delusi pandangan otonomi maupun heteronomi.

Pemahaman akan kehendak bebas manusia juga mendapat sorotan di dalam hidup Kristus yang memiliki dua natur. Artikel ketiga oleh Tonny 
Sutrisno, mahasiswa STTRII dan Billy Kristanto, dosen STTRII memiliki judul Dyothelitisme dalam Kristologi Yohanes Calvin. Sutrisno dan Kristanto mencoba melihat melihat signifikansi dua kehendak Kristus di dalam ajaran Calvin yang meneruskan ajaran orthodoks yang dirumuskan oleh Maximus. Kehendak bebas manusia Kristus merupakan bentuk ketaatannya kepada kehendak Bapa yang menuntaskan rencana keselamatan bagi umat manusia.

Ketaatan Kristus kepada Bapa juga merupakan tema sentral dalam spiritualitas rohani umat Kristen. Artikel keempat oleh Tirza Juvina Rachmadi, What Can We Learn From the Imitation of Christ of Thomas A Kempis? menyoroti signifikansi karya Kempis yang pernah sangat populer di masa lampau dan bagaimana karya ini masih tetap segar dalam nilai-nilai luhur akan pentingnya praktek ketaatan rohani. Rachmadi menemukan tiga motif penting di dalam buku ini yang melampaui batasan keterpisahan Protestantisme dan Katolisisime. Rachmadi mampu menunjukkan poin-poin penting lainnya, contohnya kritik akan praktek rohani yang salah masih relevan bahkan bagi kalangan katolik masa kini, maupun pentingnya pengajaran teologis yang pastoral demi membawa kepada kerendahan hati sejati yang memiliki daya tarik tersendiri dalam era postmodern.

Artikel kelima berjudulkan Relevansi Pandangan William Gouge Mengenai Disiplin Anak Dalam Keluarga Kristen Masa Kini di Indonesia dituliskan oleh Yuki Fran Siska, mahasiswi STTRII dan dan Jadi S. Lima, dosen STTRII. Artikel ini melanjutkan tema spiritualitas dalam kaitan disiplin yang lebih khusus kepada disiplin bagi anak-anak di dalam keluarga Kristen. Siska dan Lima mengambil pelajaran dari William Gouge yang seimbang dari dua ekstrim kekerasan dan pengabaian di dalam praktek disiplin. Tatanan ordo yang terabaikan kembali ditekankan demi menghormati otoritas yang Tuhan sudah berikan. Jika dikaitkan kembali dengan Kristus, Kristuslah anak yang taat sempurna pada pengaturan ordo dengan tunduk kepada Bapa di dalam relasi Allah Tritunggal secara ekonomis. Ketaatan Kristus menjadi contoh anak-anak menaati orang tua di dalam kesaksian keluarga Kristen.

Melalui kelima artikel yang diterbitkan di edisi jurnal Verbum Christi kali ini kita melihat pentingnya Kristus di dalam pemahaman akan Allah dan manusia dan relasi yang terjalin diantara Allah dan manusia, maupun sesama manusia. Kiranya pemahaman yang benar boleh membawa kita juga kepada praktek rohani yang benar seumur hidup kita, sehingga kita makin serupa dengan Kristus yang hidup, mati, bangkit dan naik yang mengerjakan ketaatan sempurna pro nobis. 